\title{
Sea ice and the stability of north and northeast Greenland floating glaciers
}

\author{
Niels Reeh, ${ }^{1}$ Henrik Højmark Thomsen, ${ }^{2}$ Anthony K. Higgins, ${ }^{3}$ Anker Weidick ${ }^{3}$ \\ ${ }^{1}$ Danish Center for Remote Sensing, Department of Electromagnetic Systems, Technical University of Denmark, \\ Building 348, Ørsteds Plads, DK-2800 Lyngby, Denmark \\ ${ }^{2}$ Danish Polar Center, Strandgade 100H, DK-1401 Copenhagen, Denmark \\ ${ }^{3}$ Geological Survey of Denmark and Greenland, Thoravej 8, DK-2400 Copenhagen, Denmark
}

\begin{abstract}
The interaction between sea ice and glaciers has been studied for the floating tongue of Nioghalvfjerdsfjorden glacier, northeast Greenland $\left(79^{\circ} 30^{\prime} \mathrm{N}, 22^{\circ} \mathrm{W}\right)$. Information from glacial geological studies, expedition reports, aerial photographs and satellite imagery is used to document the glacier front position and fast-ice conditions on millennial to decadal time-scales. The studies indicate that the stability of the floating glacier margin is dependent on the presence of a protecting fast-ice cover in front of the glacier. In periods with a permanent fast-ice cover, no calving occurs, but after fast-ice break-up the glacier responds with a large calving activity, whereby several years of accumulated glacier-ice flux suddenly breaks away. Climate-induced changes of sea-ice conditions in the Arctic Ocean with seasonal break-up of the near-shore fast ice could lead to disintegration of the floating glaciers. The present dominant mass loss by bottom melting would then to a large extent be taken over by grounding-line calving of icebergs. The local influx of fresh water from the north Greenland glaciers to the sea would be reduced and the local iceberg production would increase.
\end{abstract}

\section{INTRODUCTION}

Submarine and satellite-based observations show a significant decrease in extent and thickness of the Arctic sea-ice cover over the last 20-30 years (Johannessen, 1999). If continued, this could lead to a markedly different ice-ocean-atmosphere regime in the Arctic, by changing heat and mass exchanges as well as ocean stratification. This may influence the glaciation of the land areas facing the Arctic seas because of changes of snow accumulation and/or surface melting. However, changes of the near-shore sea-ice conditions may have a further impact on the land-based glaciations. Fast ice is at present common along the rim of the Arctic Ocean. In the severe climate of north and northeast Greenland, fast ice may build up to a considerable thickness and block entrances of fjords for decades (Koch, 1945; Wadhams, 1981), influencing the mass balance of the glaciers in the region. At present, many outlet glaciers from the north and northeast Greenland sectors of the Greenland ice sheet (inland ice) are characterized by extended floating sections. The semi-permanent sea-ice cover appears to protect the floating glacier tongues and prevents them from disintegrating. The major mass loss from the glaciers is by intensive bottom melting averaging several metres of ice per year (Rignot and others, 1997; Thomsen and others, 1997; Reeh and others, 1999a). The resulting fresh-water supply to the sea probably plays an important role in maintaining the semi-permanent fast-ice cover in front of the glaciers (Mayer and others, 2000).

At present, the loss by calving in the form of break-up of the frontal part of the glaciers in kilometre-sized tabular ice islands some tens of metres thick constitutes only a small fraction of the total mass loss. The ice islands drift away from the glacier fronts only when the local sea ice breaks up, a rare event which under present climate conditions takes place at intervals of up to several decades (Higgins 1989, 1991).

\section{NIOGHALVFJERDSFJORDEN GLACIER}

Interaction between glaciers and sea ice has been studied at Nioghalvfjerdsfjorden glacier, northeast Greenland $\left(79^{\circ} 30^{\prime} \mathrm{N}\right.$, $\left.22^{\circ} \mathrm{W}\right)$. The glacier is about $80 \mathrm{~km}$ long and $21 \mathrm{~km}$ wide halfway down its length, widening to about $30 \mathrm{~km}$ at the main ice front. A northern branch of the glacier, $8 \mathrm{~km}$ wide, drains into the fjord Dijmphna Sund west of Hovgaard Ø (Fig. 1). The outer $\sim 60 \mathrm{~km}$ of the glacier is afloat, with a grounding region close to the Greenland ice sheet near the western branch of the ice-dammed lake Blåsø (Fig. 1).

The main ice front of Nioghalvfjerdsfjorden glacier is divided into five sections (numbered $1-5$ in Fig. 1) by four islands, of which the three southernmost are overrun by glacier ice forming up to $40 \mathrm{~m}$ high ice rises. In the central part of the glacier, three distinct ice tongues (2-4 in Fig. 1) with characteristic sawtooth indented lateral margins extend several kilometres into the sea.

The bathymetry outside Nioghalvfjerdsfjorden is dominated by the Belgica Bank with water depths of 100-200 m (Fig. 2). It is surrounded by a $200-500 \mathrm{~m}$ deep trough system, extending from the shelf break in the south to the shelf break in the north, running close to the shore. The trough system comprises the Belgica Trough in the south, the Norske Trough running parallel to the shore and the Westwind Trough to the north (Fig. 2).

The main ice margin of the Nioghalvfjerdsfjorden glacier 


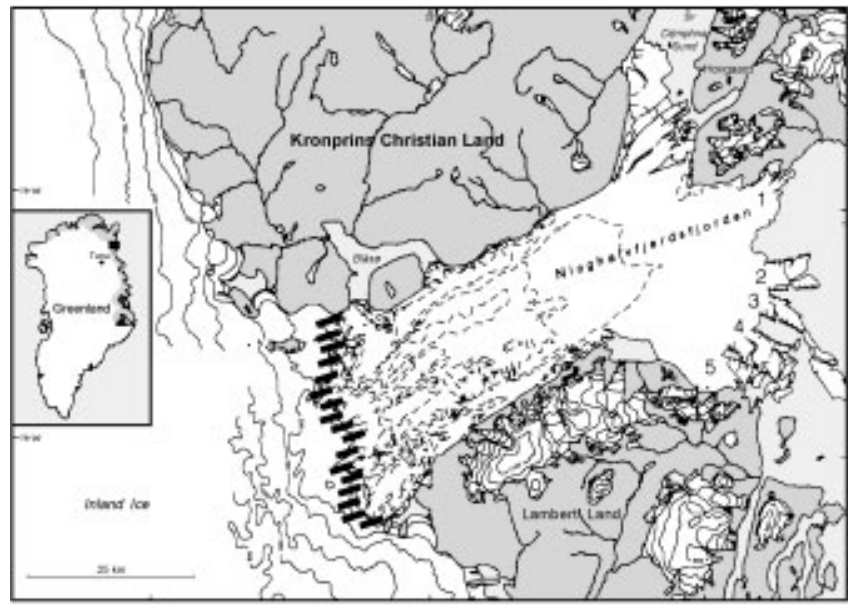

Fig. 1. Map of Nioghalvfjerdsfjorden glacier. Black rectangle in upper right corner of insert map shows the location of the glacier. Surface topography is based on photogrammetric mapping from aerial photographs from 2 August 1978. Ice-margin sections 1-5 described in the text are shown. Approximate location of the upstream grounding zone is shown by the coarse hatching running south from near the western branch of Blåso.

and its characteristic long ice tongues are enclosed in a semipermanent fast-ice barrier protecting the ice margin and preventing calving. The fast-ice barrier covers an extensive area of sea at latitudes $78-80^{\circ} \mathrm{N}$ and extends eastwards beyond the line of islands that include the Norske Øer (Fig. 2). The characteristics, extent and variation of this fast-ice barrier have been described by Budus and Schneider (1995) and Schneider and Budus $(1995,1997)$. They refer to the feature as the Norske Øer Ice Barrier (NØIB). The NØIB extends $75-150 \mathrm{~km}$ from the coast, forming the southern limit of the Northeast Water (NEW) polynya. There are significant interannual variations in the size and horizontal extent of the NØIB (Schneider and Budéus, 1995; see also Fig. 2).

\section{DATA SOURGES}

A field programme was carried out on Nioghalvfjerdsfjorden glacier in the summer seasons of 1996-98 by the Geological Survey of Denmark and Greenland, the Danish Polar Center, the Danish Center for Remote Sensing, and the Alfred Wegener Institute for Polar and Marine Research, Germany. The study comprised observations of climate, surface mass balance, bottom melting, ice thickness, glacier dynamics, tidal movement, bathymetry and conductivity-temperaturedepth measurements in the sea in front of and beneath the glacier. An account of the Nioghalvfjerdsfjorden glacier project is given by Thomsen and others (1997). Preliminary reports on the results of the project can be found in Mayer and others (1999), Reeh and others (1999b) and Thomsen and others (1999).

The Nioghalvfjerdsfjorden glacier project also comprised collection and compilation of data to document short- and long-term variations in glacier front position and the extent of the adjacent sea ice (fast ice). Variations on millennial and century time-scales are derived from glacial geological information (Bennike and Weidick, 1999). Descriptions and sketch maps in expedition reports provide information about icemargin positions in the first half of the last century (Koch and Wegener, 1912, p.7-19; Mikkelsen, 1922; Knuth, 1942;

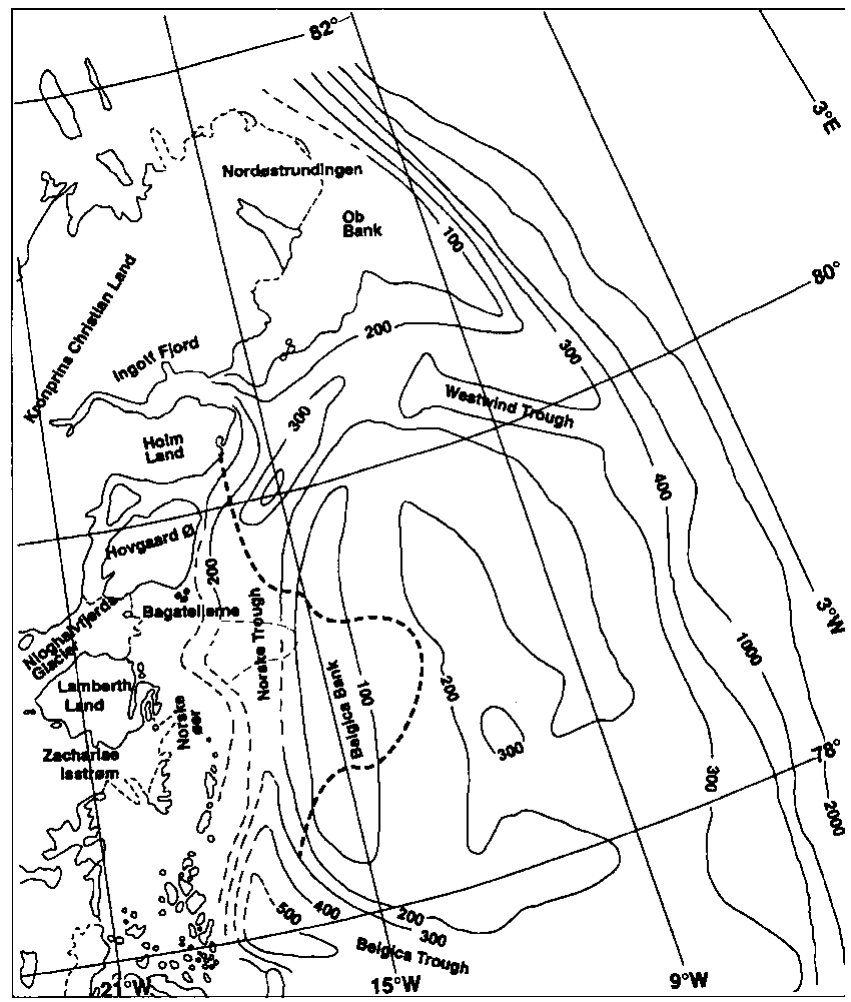

Fig. 2. Nioghalvfjerdsfjorden and surrounding areas. Bathymetry of the northeast Greenland shelf as reported by Bourke and others (1987). Variation in extent of the NØIB, 1983-93, is shown based on NOAA AVHRR images as reported by Schneider and Budéus (1995). The late-summer minimum and maximum fast-ice extent during the period are delineated with thin and thick dashed lines, respectively.

Koch, 1945). However, many of the descriptions stress the difficulty in distinguishing the low floating-glacier front from the surrounding sea ice, especially during winter and spring visits when the surface is covered with snow. The information on glacier front positions can therefore only be regarded as a guideline.

The first photographic documentation of the Nioghalvfjerdsfjorden glacier is from oblique aerial photographs taken in 1950 and 1951. Vertical aerial photographs are available from 1962/63 and 1978 in scales 1:50000 and 1:150000, respectively. Subsequent ice-front positions can be documented by data from the Landsat satellites, the first of which was launched in 1972. Cloud-free Landsat thematic mapper scenes from 1986, 1990 and 1993 have been selected for documentation of the recent ice-front positions. Furthermore a number of U.S. National Oceanic and Atmospheric Administration Advanced Very High Resolution Radiometer (NOAA AVHRR) and European Remote-sensing Satellite (ERS-2) scenes have been used to document the development of the sea-ice conditions in the vicinity of Nioghalvfjerdsfjorden.

\section{OBSERVATIONS}

\section{The Holocene}

The Holocene glaciation history of Nioghalvfjerdsfjorden and its surroundings has been documented by means of radiocarbon-dated samples of shells, driftwood, plant remains and bones collected along a transect from Blåsø in the inland area to the outer coast, and also by observations of the marine 

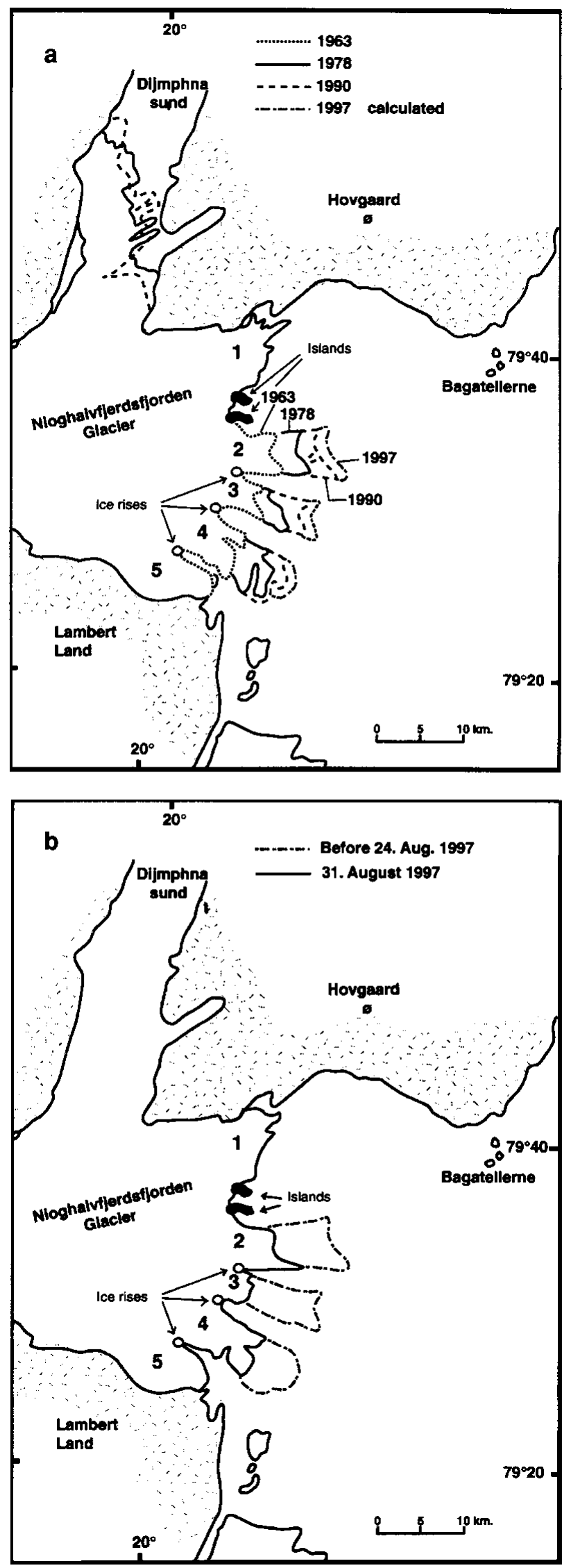

Fig. 3. (a) Ice-margin variations of Nioghalvfjerdsfjorden glacier, 1963-97. The data sources are aerial photographs from 1963 and 1978 and Landsat data from 1990. The 1997 position is projected from the mapped ice velocities at the ice margin. (b) The main ice margin of the Nioghalvfjerdsfjorden glacier before and after a major calving event triggered by the break-up of the protecting NØIB, 24-26 August 1997 (see Fig. 4). limit. The data indicate that the eastern margin of the Greenland ice sheet was still located on the offshore shelf in the early Holocene $~ 9.7$ cal. ka BP (thousand calibrated ${ }^{14} \mathrm{C}$ years before 1950) (Bennike and Weidick, 1999). The ${ }^{14} \mathrm{C}$ datings have been calibrated according to dendrochronology (Stuiver and others, 1998).

Between 7.7 and 4.5 cal. ka BP, the front of Nioghalvfjerdsfjorden glacier retreated to a position at least as far west as Blåsø. Dates of driftwood and whale-bones are restricted to the period $7.0-5.4 \mathrm{cal}$. ka BP, indicating open water in the fjord at least during this interval of the middle Holocene. The mollusc fauna and plant remains indicate that temperatures, particularly in the summer, were higher in the middle Holocene than at present (Bennike and Weidick, 1999). Since about $4 \mathrm{ka}$ BP, Nioghalvfjerdsfjorden has been permanently occupied by a floating glacier. This neo-glaciation probably culminated around AD 1900, after which a slight thinning and recession occurred.

Evidence that can throw light on the variation in extent of other north Greenland floating glaciers during the Holocene is scarce. One shell sample collected $5-10 \mathrm{~km}$ behind the present front of Steensby Gletscher $\left(81^{\circ} 30^{\prime} \mathrm{N}, 54^{\circ} \mathrm{W}\right)$ dated at 4.7 cal. ka BP (Kelly and Bennike, 1992) shows that this glacier also experienced a substantial frontal retreat in the middle Holocene.

\section{The last century}

Observations from 1906/07 (Koch and Wegener, 1912), 1910 (Mikkelsen, 1922) and 1939 (Knuth, 1942) indicate that the margin of Nioghalvfjerdsfjorden glacier was located close to the Bagatellerne islands (Fig. 2). Furthermore, Koch (1945) documents the existence of the NØIB in 1933.

Later positions of the main glacier front are based on oblique aerial photographs from 1950 and 1951. They show an ice margin with long glacier tongues stretching all the way to Bagatellerne.

Vertical aerial photographs from 1963 show that a major calving event or events occurred between 1951 and 1963, resulting in a $25 \mathrm{~km}$ retreat of the ice tongues, probably due to break-up of the protecting NØIB. Although the 1951 and 1963 photographs do not document the easternmost extent of the fast-ice cover, both sets of photographs show a glacier front confined in extended sea ice. This suggests that the NØIB ice barrier was present in both years. Support for the interpretation that the ice barrier broke up sometime in the intervening period is found in a letter of 18 November 1960 from L. Koch to A. E. Porsild (Wadhams, 1981). According to Koch, the fast-ice barrier, which formerly was attached to the glacier margin, broke away in the 1950s. Aerial photographs taken in 1978 and Landsat imagery from 1990 also show the presence of the NØIB. The characteristic sawtoothed ice tongues advanced slowly in this period, pushing eastward through the fast-ice barrier (see Fig. 3a). Based on the length of the ice tongues, a rate of advance of $160-180 \mathrm{~m} \mathrm{a}^{-1}$ is estimated in accordance with more recent measurement of ice velocities (Reeh and others, 1999b). The advance took place without any major changes in the ice-tongue configuration, and icebergs in front of the glacier were slowly pushed seaward without being rotated. The same pattern of advance continued until 1997, as documented by field observations in that year. However, as accurate measurement of the ice-margin position was not undertaken in 1997, the 1997 position 

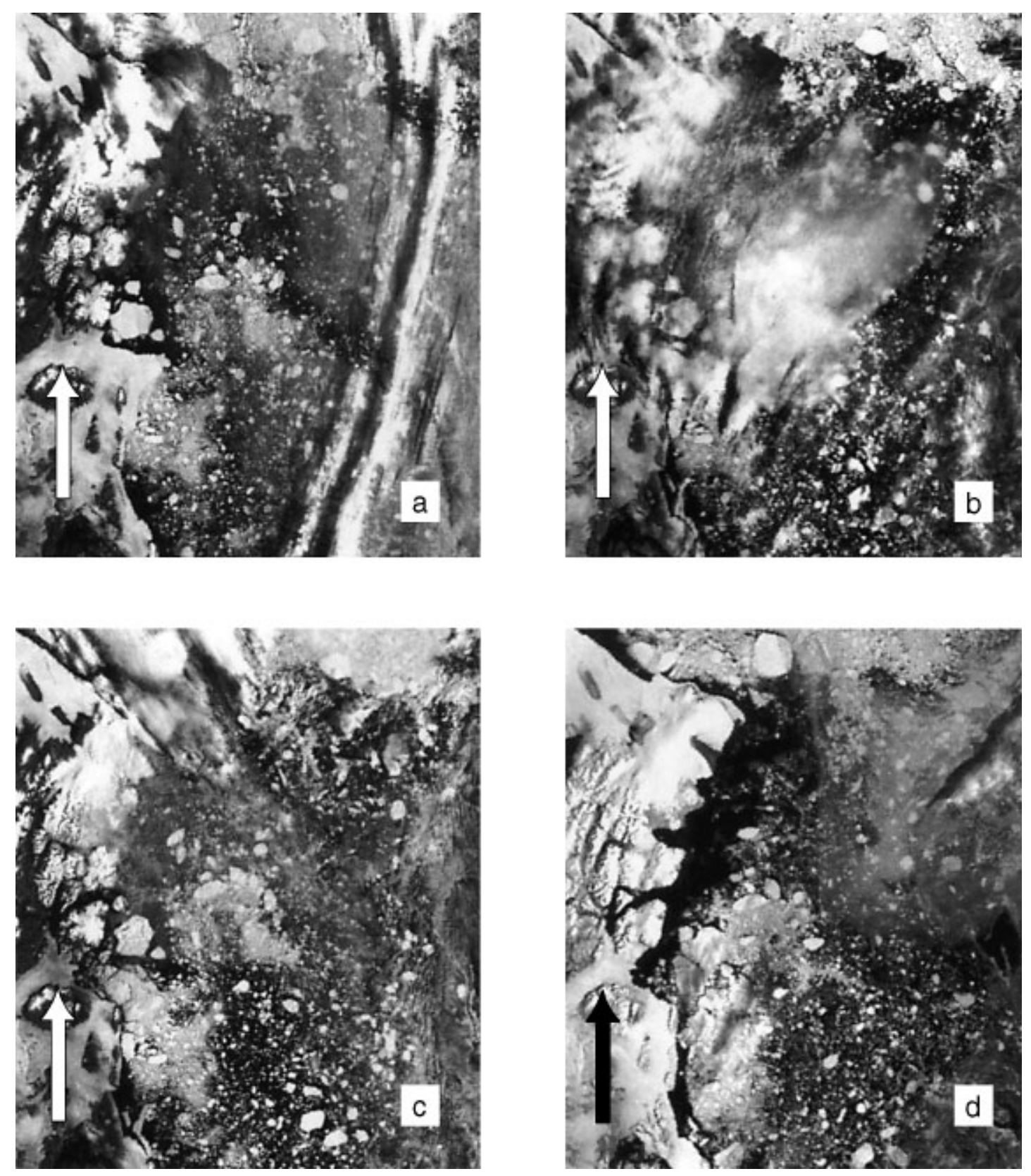

Fig. 4. NOAA AVHRR documentation of the break-up of the NØIB, August 1997. White or black arrows show the location of the Nioghalvfjerdsfjorden glacier. (a) 24 August 1997. The ice barrier is seen to the right of the arrow. (b) 26 August 1997. Although the image is partly obscured by clouds, it is evident that break-up of the ice barrier has begun. (c) 27 August 1997. (d) 3 September 1997.

shown in Figure 3a is extrapolated by means of the measured velocities at the margin.

The ice margin in Dijmphna Sund has not shown a similar advance. The more frequent disappearance of the fjord ice in Dijmphna Sund has apparently resulted in frequent calving events.

\section{The August 1997 event}

NOAA AVHRR data document that the NØIB broke up again between 24 and 26 August 1997 (Fig. 4), apparently after having existed since at least 1963, i.e. for $>34$ years (see previous subsection). Figure 4 shows that the ice barrier broke up into several large floes that, during the days after the break-up, moved slowly east towards Belgica Bank. On 3 September 1997, open water was observed from the Northeast Water polynya all the way south to the margin of Nioghalvfjerdsfjorden glacier (Fig. 4). The cause of the fast-ice break-up is so far unknown.

The break-up of the fast-ice barrier (NØIB) triggered major calving from the glacier in Nioghalvfjerdsfjorden, as documented by an ERS-2 image from 31 August 1997 (Fig. 5). The ice-front positions before and after the calving are shown in Figure 3b. Most of ice tongues 2 and 3 have calved away, as well as a large part of ice tongue 4 . Many icebergs have moved into the open water in front of the glacier, with only a few remaining along the southern shore of Hovgaard Ø (Fig. 5). The calving from ice tongues 2-4 represents a glacier area of $92 \mathrm{~km}^{2}$. With an estimated ice thickness of $80 \mathrm{~m}$ (Reeh and others, 1999b) the calved-off ice volume amounts to about $7.4 \mathrm{~km}^{3}$. Compared to a total ice flux of $0.2 \mathrm{~km}^{3} \mathrm{a}^{-1}$ from this part of the ice margin (Reeh and others, 1999a), the August 1997 calving event therefore corresponds to about 35 years of ice flux at the main ice 


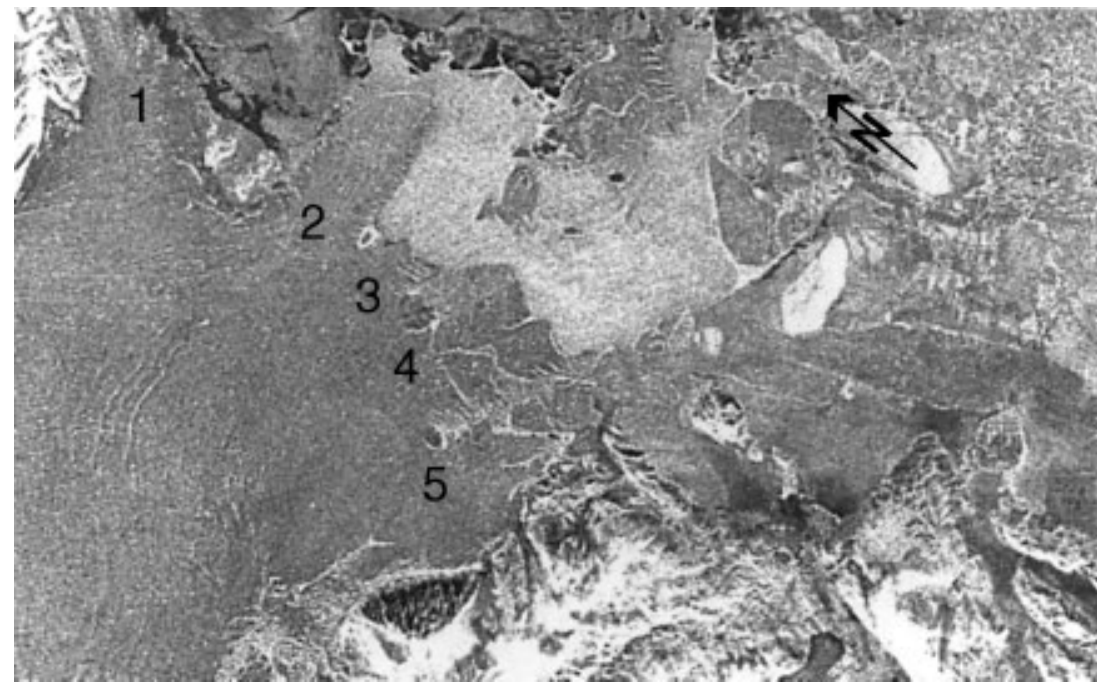

Fig. 5. ERS-2 image from 31 August 1997 of the main ice front of Nioghalvfjerdsfjorden glacier after a major calving. Numbers 1-5 refer to the ice-margin sections shown in Figure 1. Notice north arrow in upper right corner.

front, which indicates that no major calving or ice-front break-up occurred during this 35 year period. This period without major calving activity coincides with the period in which the NØIB was most likely permanently present.

Recent NOAA AVHRR and Landsat-7 images reveal that the NØIB has once again re-formed after the sudden break-up in August 1997. Field observations in the area in 1998 show that the large icebergs released from the glacier front at the break-up in 1997 are now trapped within the fast ice of the re-formed NØIB.

\section{FAST-IGE/GLACIER INTERACTION}

The course of events described in the previous sections suggests that the infrequent occurrences of fast-ice break-up and break-up of the ice tongues from Nioghalvfjerdsfjorden glacier are interrelated. The stability of the floating ice margin seems to be dependent on the presence of a protecting fast-ice cover in front of the glacier. In periods with a permanent fast-ice cover, no calving takes place from the ice tongues. In these periods the glacier advances slowly through the sea ice, or pushes the sea ice ahead of itself, with essentially no change of the ice-margin configuration. During fast-ice break-up, the glacier responds with major calving activity, whereby several years of accumulated glacier-ice flux suddenly breaks away.

The same procedure applies to other north Greenland floating glaciers, as documented by $\operatorname{Higgins}(1989,1991)$ on the basis of aerial photographs taken at decadal intervals.

There are several mechanisms by which a semipermanent fast-ice cover could inhibit calving/disintegration of a floating glacier front. It is not within the scope of this work to provide a comprehensive analysis of what is a complicated dynamic system, but a few possible mechanisms are discussed below:

(a) Sea ice may apply sufficient back-pressure to prevent crevasse formation and/or propagation

(b) Sea ice may damp long ocean waves, thereby reducing bending stresses in the floating glacier that might result in fracture.

(c) By suppressing wind-generated waves, sea ice may reduce mixing of the water masses in front of the glacier, thereby preventing contact of the glacier front with deep, warm, saline water that might cause undercutting of the glacier front and subsequent calving.

(d) Sea ice may "glue" or maybe just keep together the partly or fully disintegrated frontal region of the glacier, preventing icebergs from drifting away.

As mentioned previously, calving from the thin north Greenland floating glaciers is mainly in the form of disintegration of the frontal region into kilometre-sized tabular icebergs, whereas calving of "West Greenlandtype" icebergs with dimensions on the order of magnitude of the glacier thickness or less is insignificant. The crevasses that eventually determine the pattern of frontal disintegration are formed behind the glacier terminus in zones of strong horizontal shearing or bending because of obstacles causing abrupt changes in speed or direction of the glacier motion.

If mechanism (a) plays any role, one would expect to see pressure ridges in the fast-ice cover in front of the glacier front. Such ridges are not observed at Nioghalvfjerdsfjorden. An unconfined fast-ice barrier like the NØIB (see Fig. 2) probably has little potential for exerting back-pressure. However, in front of Steensby Gletscher, a floating north Greenland glacier located at $81^{\circ} 30^{\prime} \mathrm{N}, 54^{\circ} \mathrm{W}$ in a $3-4 \mathrm{~km}$ wide fjord, pressure ridges occurred in the confining fast-ice cover (Ahnert, 1963). Although mechanism (a) is considered unimportant in the case of Nioghalvfjerdsfjorden glacier, it may thus play some role for other floating north Greenland glaciers.

A fast-ice cover with an extent of $50-100 \mathrm{~km}$ will certainly damp even long ocean waves (Squire and Moore, 1980). However, even without being damped by a sea-ice cover, it is unlikely, that ocean-wave action could set up significant bending stresses in the $>80 \mathrm{~m}$ thick floating Nioghalvfjerdsfjorden glacier. This would require significant ocean-wave-induced pressure fluctuations at the underside of the glacier. Significant wave-generated pressure fluctuations at this depth are unlikely because the shallow water depths on the shelf outside the glacier will prevent the necessary long ocean waves from propagating to near the glacier front. We therefore tend also to reject mechanism (b) as an important calving-inhibiting mechanism.

For similar reasons, mechanism (c) can probably be 
excluded. The damping of ocean waves due to a fast-ice cover will certainly reduce vertical mixing of the water masses near the glacier front as compared to a situation without fast ice. However, relatively warm, salty water with the potential to generate melting is found only at depths of $>150 \mathrm{~m}$ (Mayer and others, 2000). Effective wave-generated vertical mixing down to this depth is rather unlikely, even without a fast-ice cover.

So, we are left with the explanation that the main effect of the fast-ice cover is to keep the partly disintegrated glacier front from splitting up, and the fragments from drifting away as ice islands.

At present, there is a change in fjord-glaciation characteristics in Greenland from grounding-line calving glaciers in the south to extended floating glaciers subject to intensive bottom melting in the north. Reeh and others (1999a) suggested that this change is controlled by climate. Summer temperatures in north Greenland only a few ${ }^{\circ} \mathrm{C}$ higher than now would most likely cause seasonal break-up of the near-shore sea ice in contrast to break-up at intervals of several decades under present climatic conditions (Reeh and others, 1999a). Under such warmer conditions, the floating glaciers are likely to disintegrate. As documented in a previous section, the glacial geological record from Nioghalvfjerdsfjorden shows that icebarrier break-up and floating-glacier retreat did occur during the Holocene climatic optimum.

The coexistence of floating glaciers and semi-permanent fast ice does not in itself prove a causal relationship between their occurrences. Both phenomena could very well owe their existence to the present climatic conditions in north and northeast Greenland. A simple melt-rate model (Reeh, 1991) shows that, at sea level, the surface melt rate of glaciers in north Greenland will increase by about $2.5 \mathrm{~m} \mathrm{a}^{-1}$ if summer temperatures increase by $2^{\circ} \mathrm{C}$. Using measured ice velocities on Nioghalvfjerdsfjorden glacier, a simple calculation shows that it takes of the order of 100 years for the glacier ice to travel the distance of about $60 \mathrm{~km}$ from the grounding zone to the glacier terminus. After 100 years with summer temperatures $2{ }^{\circ} \mathrm{C}$ warmer than now, the front region of the glacier would have thinned by an estimated $\sim 250 \mathrm{~m}$ due to increased surface melting. As large sections of Nioghalvfjerdsfjorden glacier (and other north Greenland floating glaciers) are $<250 \mathrm{~m}$ thick, increased surface melting would in such a scenario result in the disappearance of large areas of the present floating glaciers in north Greenland over $<100$ years, assuming unchanged basal melt rates. Reduced contact with pinning points such as ice rises, and reduced support along the side margins would further enhance the rate of deterioration by promoting disintegration of the floating glacier into large icebergs.

Although the floating glaciers in north Greenland will thus respond to climate change independent of changes of the fast-ice cover, it is also clear that the occurrence of floating glaciers and fast ice is in some respect interdependent. Only in the infrequent event of break-up of the fast-ice cover does disintegration of the glacier-ice tongues into large icebergs occur. On the other hand, the existence of the fastice cover probably depends on the large amount of fresh water produced by melting at the bottom of the floating glaciers. The total fresh-water volume produced by bottom melting from north Greenland floating glaciers is estimated at about $35 \mathrm{~km}^{3} \mathrm{a}^{-1}$, of which Nioghalvfjerdsfjorden glacier accounts for about $13 \mathrm{~km}^{3} \mathrm{a}^{-1}$ (Reeh and others, 1999a). The meltwater moves up the gradient at the underside of the floating glaciers towards the terminus and spreads beneath the fast-ice cover in front of the glacier terminus. The layer of cold, fresh and relatively low-density meltwater stabilizes the sea-ice cover by preventing its contact with the warmer, more salty and denser sea water beneath (Mayer and others, 2000).

\section{SUMMARY AND GONGLUSIONS}

Dated biogenic material shows that the present $60 \mathrm{~km}$ long floating part of Nioghalvfjerdsfjorden glacier had disappeared between 7.7 and $4.5 \mathrm{kaBP}$, i.e. during the Holocene climatic optimum, when summer temperatures in East Greenland were several ${ }^{\circ} \mathrm{C}$ higher than now. During this period, a fjord with open water in the summer extended about $60 \mathrm{~km}$ inland from the present glacier front. It is most likely that a glacier producing icebergs by grounding-line calving was situated at the head of Nioghalvfjerdsfjorden at that time.

For the period since the early part of last century, expedition reports, aerial photographs and satellite images show the following typical behaviour of the glacier. For several decades the glacier advances in the form of long ice tongues protruding between islands and ice rises. The ice tongues are enclosed in semi-permanent fast ice, which apparently protects the glacier ice tongues and prevents calving. With intervals of several decades, the sea-ice barrier breaks up and the protruding ice tongues disintegrate in kilometre-sized ice islands with a volume corresponding to several decades of accumulated glacier-ice flux.

In a climate a few ${ }^{\circ} \mathrm{C}$ warmer than the present, semipermanent fast ice and floating glaciers are unlikely to exist in north and northeast Greenland. As a consequence, the present direct meltwater input to the ocean produced by bottom melting of north and northeast Greenland floating glaciers (about $35 \mathrm{~km}^{3} \mathrm{a}^{-1}$ ) is likely to decrease to near zero. This could have an impact on local sea-ice growth, and hence influence deep-water formation and the extent of polynyas. Also, a significant increase of the iceberg density along the East Greenland coast is to be expected, particularly north of Scoresby Sound, where, presently, drifting icebergs are seldom encountered. At present, the total ice flux across the grounding lines of north Greenland floating glaciers is about $50 \mathrm{~km}^{3} \mathrm{a}^{-1}$ (Rignot and others, 1997). Instead of being removed by bottom melting, as happens today, most of this volume will in a warmer climate eventually be released as icebergs by grounding-line calving. The icebergs, no longer trapped by semi-permanent sea ice, will join the large-scale oceanic circulation and be transported southward, as both bathymetry and the near-coast sea currents give the icebergs access to the East Greenland Polar Current.

\section{ACKNOWLEDGEMENTS}

This research was supported by the Commission of the European Communities under contract ENV4-CT95-0124, by the Commission for Scientific Research in Greenland and by the Danish Natural Sciences Research Council. Research results based on Geological Survey of Denmark and Greenland (GEUS) material are published with the permission of the GEUS. The manuscript was improved by comments from two anonymous reviewers. 


\section{REFERENCES}

Ahnert, F. 1963. The terminal disintegration of Steensby Gletscher, north Greenland. 7. Glaciol., 4(35), 537-545.

Bennike, O. and A. Weidick. 1999. Observations on the Quaternary geology around Nioghalvfjerdsfjorden, eastern North Greenland. Geol. Greenl. Surv. Bull. 183, 57-60.

Bourke, R. H., J. L. Newton, R. G. Paquette and M. D. Tunnicliffe. 1987. Circulation and water masses of the East Greenland Shelf. 7. Geophys. Res., 92(C7), 6729-6740.

Budéus, G. and W. Schneider. 1995. On the hydrography of the Northeast Water Polynya. 7. Geophys. Res., 100(C3), 4287-4299.

Higgins, A. K. 1989. North Greenland ice islands. Polar Rec., 25(154), 207-212.

Higgins, A. K. 1991. North Greenland glacier velocities and calf ice production. Polarforschung, 60(1), 1990, 1-23.

Johannessen, O. M., E.V. Shalina and M.W. Miles. 1999. Satellite evidence for an Arctic sea ice cover in transformation. Science, 286(5446), 1937-1939.

Kelly, M. and O. Bennike. 1992. Quaternary geology of western and central North Greenland. Gronl. Geol. Undersøgelse, Rapp. 153.

Knuth, E. 1942. Dansk Nordøstgrønlands Ekspedition 1938-39. Report on the expedition and subsequent work at the Mørkefjord Station. Medd. Gronl., $126(1)$.

Koch, I. P. and A. Wegener. 1912. Die glaziologischen Beobachtungen der Danmark-Expedition. Medd. Gronl., 46(1).

Koch, L. 1945. The East Greenland ice. Medd. Gronl., 130 (3).

Mayer, C., F. Jung-Rothenhäusler, P. Huybrechts and E. Le Meur. 1999. Investigations on Nioghalvfjerdsfjorden glacier, NE Greenland. In Climate change and sea level: final report of work undertaken for the Commission of the European Communities under contract No. ENV4-CT095-0124, 1st March 1996- 28 February 1999. Bremerhaven, Alfred Wegener Institute for Polar and Marine Research. (Report 7.)

Mayer, C., N. Reeh, F. Jung-Rothenhäusler, P. Huybrechts and H. Oerter. 2000. The subglacial cavity and implied dynamics under Nioghalvfjerdsfjorden glacier, NE-Greenland. Geophys. Res. Lett., 27(15), 2289-2292.

Mikkelsen, E. 1922. Alabama-Expeditionen. Til Grønlands Nordøstkyst
1909-1912. Medd. Gronl. 52.

Reeh, N. 1991. Parameterization of melt rate and surface temperature on the Greenland ice sheet. Polarforschung, 59(3), 1989, 113-128.

Reeh, N., C. Mayer, H. Miller, H. H. Thomsen and A. Weidick. 1999a. Present and past climate control on fjord glaciations in Greenland: implications for IRD-deposition in the sea. Geophys. Res. Lett., 26(8), 1039-1042.

Reeh, N., H. H. Thompson, A. K. Higgins, A. Weidick and W. Starzer. 1999b. Stability conditions of north-east Greenland floating ice margins. In Climate change and sea level: final report of work undertaken for the Commission of the European Communities under contract No. ENV4-CT0950124, 1 March 1996- 28 February 1999. Copenhagen, Danish Polar Center. (Report 9.)

Rignot, E. J., S. P. Gogineni, W. B. Krabill and S. Ekholm. 1997. North and north-east Greenland ice discharge from satellite radar interferometry. Science, 276(5314), 934-937.

Schneider, W. and G. Budéus. 1995. On the generation of the Northeast Water Polynya. 7. Geophys. Res., 100(C3), 4269-4286.

Schneider, W. and G. Budéus. 1997. A note on Norske Ø Ice Barrier (Northeast Greenland), viewed by Landsat 5 TM. 7. Mar. Syst., 10(1-4), 99-106.

Squire, V. A. and S. C. Moore. 1980. Direct measurement of the attenuation of ocean waves by pack ice. Nature, 283(5745), 365-368.

Stuiver, M. and 9 others. 1998. INTERCAL98 radiocarbon age calibration, 24,000-0 cal BP. Radiocarbon, 40(3), 1041-1083.

Thomsen, H. H. and 6 others. 1997. The Nioghalvfjerdsfjorden glacier project, north-east Greenland: a study of ice sheet response to climate change. Geol. Greenl. Surv. Bull. 176, 95-103.

Thomsen, H. H., N. Reeh, O. B. Olesen, W. Starzer and C. E. Bøggild. 1999. Bottom melting, surface mass-balance and dynamics of floating northeast Greenland ice tongues. Participant No. 3. In Climate change and sea level: final report undertaken for the Commission of the European Communities under contract No. ENV4-CT095-0124, 1 March 1996- 28 February 1999. Copenhagen, Geological Survey of Denmark and Greenland. (Report 8.)

Wadhams, P. 1981. The ice cover in the Greenland and Norwegian Seas. Rev. Geophys. Space Phys., 19 (3), 345-393. 